\title{
Assignment of the gene encoding renin binding protein (Renbp)to rat chromosome Xq37 by in situ hybridization and radiation hybrid mapping
}

\author{
H. Zürcher, ${ }^{a, b}$ P. Van Vooren, ${ }^{c}$ J . Szpirer, ${ }^{c}$ C. Szpirer, ${ }^{c}$ and R. Kreutza,b \\ Departments of a Clinical Pharmacology and ${ }^{\mathrm{b}}$ Medicine IV Nephrology, Benjamin Franklin Hospital, \\ Freie Universität Berlin (Germany) \\ ${ }^{c}$ Department of Molecular Biology, Université Libre de Bruxelles (Belgium)
}

\section{Rationale and significance}

The renin-angiotensin system (RAS) plays a crucial role in the regulation of blood pressure (Laragh, 1995). Within the RAS, the physiological relevance of renin binding protein $(\mathrm{RnBP})$ has been controversial for several years (Schmitz et al., 2000). Originally, RnBP was identified as a protein in the kidney that was capable of binding renin in renal homogenates giving rise to a complex designated high molecular weight renin (Takahashi et al., 1983). It was subsequently proposed that $\mathrm{RnBP}$ might act as an endogenous cellular renin inhibitor. Recent studies demonstrated that human RnBP is the enzyme $\mathrm{N}$-acetyl-D-glucosamine (GlcNAc) 2-epimerase (Takahashi et al., 1999). Moreover, gene-targeting experiments in the mouse excluded a specific interaction between RnBP and renin in the kidney or in the circulating RAS of the mouse (Schmitz et al., 2000). So far, the gene encoding RnBP has been mapped on chromosome $\mathrm{X}$ in different mammals: Xq28 in human (van den Ouweland et al., 1994), X $29.53 \mathrm{cM}$ in mouse (http:// www.ncbi.nlm.nih.gov/LocusLink/LocRpt.cgi?l=19703) and X

\footnotetext{
R.K. was supported by a grant from the DFG (KR 1152/2-1). The work was also supported by the Fund for Scientific Medical Research (FRSM), Belgium. C.S. is a Research Director of the National Fund for Scientific Research (FNRS), Belgium. We are grateful to Heike Marquardt for technical support.

Received 4 April 2002; manuscript accepted 5 June 2002

Corresponding author: Reinhold Kreutz, MD

Department of Clinical Pharmacology, Benjamin Franklin Hospital

Freie Universität Berlin, Hindenburgdamm 30, D-12200 Berlin (Germany) telephone: +49-30-8445-2280; fax: +49-30-8445-4482

e-mail:kreutz@medizin.fu-berlin.de
}

in canine (Stoy et al., 1998). As mapping data for the rat homo$\log$ Renbp is still lacking, it is unclear whether this gene is located in blood pressure quantitative trait loci (QTL) termed $B P / S P$ - 2 and $S S-X$ on rat chromosome $\mathrm{X} . B P / S P 2$ has been identified in an intercross between the stroke prone spontaneously hypertensive rat (SHRSP) and the normotensive Wistar-Kyoto (WKY) rat (Hilbert et al., 1991) and $S S$ - $X$ has been characterized in the Sabra hypertension-prone rat (Yagil et al., 1999). We therefore set out to test the chromosome location of Renbp by performing chromosomal mapping analysis in the rat using fluorescence in situ hybridization (FISH) and radiation hybrid (RH) mapping.

\section{Materials and methods}

Fluorescence in situ hybridization

A 1092-bp rat Renbp cDNA fragment spanning a region between position 140 and 1232 of the reported mRNA sequence (Inoue et al., 1991; GenBank accession no. D10233) was generated by reverse transcription PCR as reported (Kreutz et al., 1997) using the following oligonucleotides: 5'CCTTGGCCGCGATGGGCAGGTATATG- ${ }^{\prime}$ and $5^{\prime}$-GGGGCGGGCCCAAGGCGTTGGAGTAG-3'. The FISH experiments were done as previously described (Laes et al., 1998).

\section{Probe name: Renbp}

Probe type: cDNA

Proof of authenticity: Amplifiable with specific primers and sequencing. Gene reference: Inoue et al. (1991); GenBank accession no. D10233

\section{Radiation hybrid mapping}

$50 \mathrm{ng}$ of genomic DNA from the rat-hamster radiation hybrid panel (Research Genetics, http://www.resgen.com) were amplified with a set of primers specific for a segment of the rat Renbp gene in exon 5. PCR was performed on all 106 clones of the RH-panel (Steen et al., 1999; Watanabe et al., 1999) and analyzed by gel electrophoresis. The data vector obtained for Renbp was: 000010010000000000000010100000000000000000001

\begin{tabular}{lll}
\hline KARGER & $\begin{array}{l}\text { Fax }+41613061234 \\
\begin{array}{l}\text { E-mail karger@karger.ch } \\
\text { www.karger.com }\end{array}\end{array}$ & $\begin{array}{l}\text { ○ 2002 S. Karger AG, Basel } \\
0301-0171 / 02 / 0974-0276 \$ 18.50 / 0\end{array}$
\end{tabular}

Accessible online at:

www. karger.com/cgr 

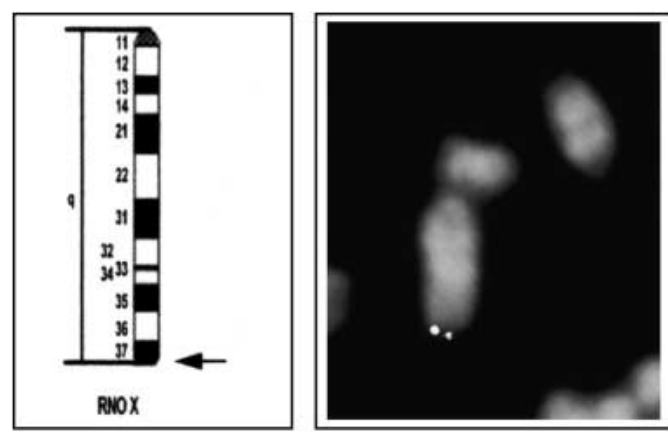

Fig. 1. Regional localization of Renbp on rat chromosome X. Portion of a rat cell metaphase showing the signals generated by the probe at Xq37. The chromosomes were DAPI-counterstained and the banding and probe signal images were captured and treated with the ISIS imaging system (MetaSystems, Althussheim, Germany).

1001101001010100110000011001000100001010011000000000001 011000 . The results of presence or absence of PCR amplification were entered into the web page of the Otsuka GEN Research Institute (http:// ratmap.ims.u-tokyo.ac.jp/). The mapping position was determined using MultiMap at the same web page (Matise et al., 1994).

$\begin{array}{ll}\text { Primer names: } & \text { Primer sequences: } \\ \text { Renbp-S: } & \text { 5'-ACCGCCTGGCAAGAAATGTG-3' } \\ \text { Renbp-AS: } & 5^{\prime} \text {-CACAGTTCATTCATGGCCATGGTGTA-3 } \\ \text { PCR conditions: } & 94^{\circ} \mathrm{C} 15 \mathrm{~s}, 60^{\circ} \mathrm{C} 60 \mathrm{~s}, 72^{\circ} \mathrm{C} 60 \mathrm{~s} \text { (30 cycles) }\end{array}$

Proof of authenticity: Amplification with the primers generated a specific band at the expected size of 111 bp of Renbp exon 5, which was confirmed by sequencing.

\section{Results}

RH mapping with the vector from exon 5 and an additional independent vector obtained by PCR amplification of a sequence from intron 9 (data not shown) revealed linkage to both RNO1 (maximum lod score 9.0) and RNOX (maximum lod score 9.4). FISH analysis, however, showed that Renbp is located on chromosome X at Xq37 (Fig. 1). This result was confirmed by somatic cell hybrid analysis (data not shown). Chromosomal placement on the X chromosome by RH mapping confirmed the telomeric localization of Renbp close to marker DXWox3 (Fig. 2). Placement for Renbp was next to DXWox3, $26.4 \mathrm{cR}$ away from the closest marker D19Mit1 (D19Mit1 represents a marker previously localized on rat chromosome 19 , but reassigned to chromosome X (Bihoreau et al., 1997) on one side and $28.4 \mathrm{cR}$ away from flanking marker DXRat22 on the other side. Construction of a comparative map integrating the previously reported confidence intervals for the placement of the blood pressure QTL $B P / S P$-2 between markers DXMgh5 and DXMit4 (SHRSP $\times$ WKY intercross; Hilbert et al., 1991) and $S S-X$ between markers DXRat 4 and DXMgh 10 (Sabra rat model, Yagil et al., 1999) revealed that Renbp falls outside the BP QTL regions on chromosome X (Fig. 2).

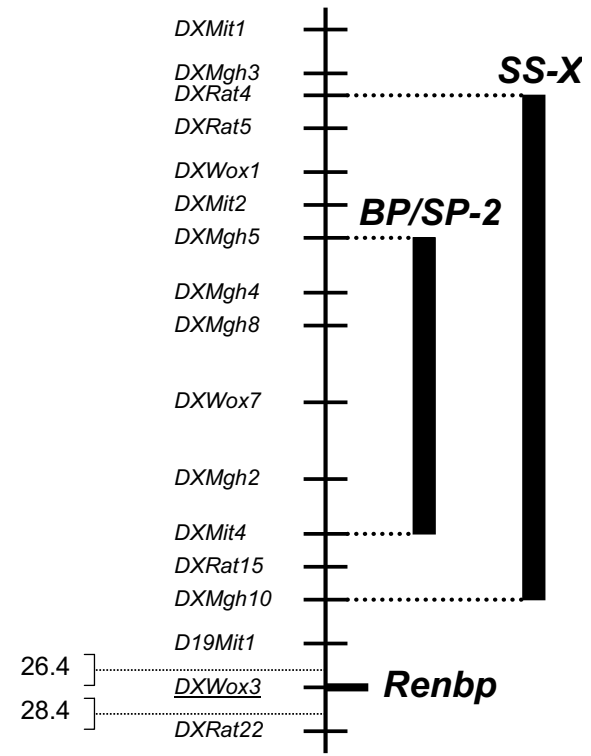

Fig. 2. RH-mapping of Renbp. The mapping position of Renbp is indicated by a thick horizontal bar, the corresponding microsatellite marker DXWox3 is underlined. The thick vertical bars on the right indicate the QTL intervals of $B P / S P$-2 (a QTL previously identified in a cross between SHRSP $\times \mathrm{WKY}$ ) and $S S-X$ (a QTL previously identified in the Sabra rat model); and the dotted horizontal lines indicate the borders of the confidence intervals, respectively. Genetic distances in centiRay (cR) to the closest markers around Renbp are shown on the left (not drawn to scale).

\section{Mapping data for Renbp}

Most precise location: $\mathrm{Xq} 37$

Number of cells examined: 13

Number of cells with specific signal: 1 (3), 2 (9), 3(1) chromatids per cell.

\section{References}

Bihoreau MT, Gaugier D, Kato N, Hyne G, Lindpaintner K, Rapp JP, James MR, Lathrop GM: A linkage map of the rat genome derived from three F2 crosses. Genome Res 7:434-440 (1997).

Hilbert P, Lindpaintner K, Beckmann JS, Serikawa T, Soubrier F, Dubay C, Cartwright $\mathrm{P}$, De GB, Julier C, Takahasi S: Chromosomal mapping of two genetic loci associated with blood-pressure regulation in hereditary hypertensive rats. Nature 353:521-529 (1991).

Inoue H, Takahashi S, Fukui K, Miyake Y: Genetic and molecular properties of human and rat renin-binding proteins with reference to the function of the leucine zipper motif. J Biochem 110:493-500 (1991).

Kreutz R, Struk B, Rubattu S, Hübner N, Szpirer J, Szpirer C, Ganten D, Lindpaintner K: Role of the $\alpha-, \beta$-, and $\gamma$-subunits of epithelial sodium channel in a model of polygenic hypertension. Hypertension 29:131-136 (1997)

Laes JF, Van Vooren P, Szpirer J, Szpirer C: Assignment of the cyclin-dependent kinase inhibitor genes $C d k n 2 a$ and $C d k n 2 b$ to rat chromosome bands $5 \mathrm{q} 33$ and $5 q 32$, respectively by fluorescence in situ hybridization, using small PCR-generated probes. Cytogenet Cell Genet 81:290-291 (1998).

Laragh JH: Renin-angiotensin-aldosterone system for blood pressure and electrolyte homeostasis and its involvement in hypertension, in congestive heart failure and in associated cardiovascular damage (myocardial infarction and stroke). J hum Hypertens 9:385-390 (1995).

Matise TC, Perlin M, Chakravarti A: Automated construction of genetic linkage maps using an expert system (MultiMap): a human genome linkage map. Nature Genet 6:384-390 (1994).

Schmitz C, Gotthardt M, Hinderlich S, Leheste JR, Gross V, Vorum H, Christensen EI, Luft FC, Takahashi S, Willnow TE: Normal blood pressure and plasma renin activity in mice lacking the renin-binding protein, a cellular renin inhibitor. J biol Chem 275:15357-15362 (2000). 
Steen RG, Kwitek-Black AE, Glenn C, Gullings-Handling J, Van Etten W, Scott Atkinson O, Appel D, Twigger S, Muir M, Mull T, Granados M, Kissebah M, Russo K, Crane R, Popp M, Peden M, Matise T, Brown DM, Lu J, Kingsmore S, Tonellato PJ, Rozen S, Slonim D, Young P, Knoblauch M, Provoost AP, Ganten $\mathrm{D}$, Colmann SD, Rothberg J, Lander E, Jacob H: A high-density integrated genetic linkage and radiation hybrid map of the laboratory rat. Genome Res 9:AP1AP8 (1999).

Stoy SJ, Shibuya H, O'Brien D, Johnson GS: A BsII PCR/RFLP in the renin binding protein (RnBP) gene on canine chromosome X. Anim Genet 29:327-328 (1998).

Takahashi S, Ohsawa T, Miura R, Miyake Y: Purification of high molecular weight (HMW) renin from porcine kidney and direct evidence that the HMW renin is a complex of renin with renin binding protein (RnBP). J Biochem 93:265-274 (1983).
Takahashi S, Takahashi K, Kaneko T, Ogasawara H, Shindo S, Kobayashi M: Human renin-binding protein is the enzyme $\mathrm{N}$-acetyl-D-glucosamine 2-epimerase. J Biochem 125:348-353 (1999).

van den Ouweland AM, Verdijk M, Kiochis P, Poustka A, van Oost BA: The human renin-binding protein gene (RENBP) maps in Xq28. Genomics 21:279-281 (1994).

Watanabe TK, Bihoreau MT, McCarthy LC, Kiguwa SL, Hishigaki H, Tsuji A, Browne J, Yamasaki Y, Mizoguchi-Miyakita A, Oga K, Ono T, Okuno S, Kanemoto N, Takahashi E, Tomita K, Hayashi H, Adachi M, Webber C, Davis M, Kiel S, Knights C, Smith A, Critcher R, Miller J, James MR: A radiation hybrid map of the rat genome containing 5,255 markers. Nature Genet 22:27-36 (1999).

Yagil C, Sapojnikov M, Kreutz R, Zürcher H, Ganten D, Yagil Y: The role of chromosome $\mathrm{X}$ in the Sabra rat model of salt-sensitive hypertension. Hypertension 33:261-265 (1999). 